\title{
AC 2007-2594: INTRODUCING ENGINEERING AND TECHNOLOGY TO NON-MAJORS: BENEFITS, CHALLENGES, AND OPPORTUNITIES IN OFFERING A TECHNOLOGICAL LITERACY COURSE
}

\section{John Blake, Austin Peay State University}

Biographical Information JOHN W. BLAKE is an Associate Professor with the Department of Engineering Technology at Austin Peay State University, Clarksville, TN. He received his B.S., M.S., and Ph.D. in Mechanical Engineering from Northwestern University, and is a registered Professional Engineer in the State of Tennessee. 


\title{
Introducing Engineering and Technology to Non-Majors: Benefits, Challenges, and Opportunities in Offering a Technological Literacy Course
}

\begin{abstract}
The National Academy of Engineering and other organizations have stressed the need for the general public to be better informed about engineering and technology. To help address this concern, engineering and engineering technology departments can develop and offer courses on technological literacy for non-majors. This paper will discuss the author's experience in developing and offering such a course for non-majors at a small state university with a strong attachment to the liberal arts. The course is intended to give students a basic appreciation of technology and of the engineering profession, an understanding of how technological progress occurs, a recognition of how technological change has both positive and negative effects on the way people live, a sense of both the potentials and the limits of technological progress, and, finally, a vision of things to come. Students who complete the course should be better able to make informed decisions on technological issues as citizens and in their careers.
\end{abstract}

When offering a technological literacy course for non-majors, one challenge is to attract students to the course. The paper will discuss target audiences and ideas on how to make the course appealing to students. If faculty colleagues in other departments recognize the value of technological literacy in their own areas, they may be willing to recommend such a course to their students. To this end, the paper will also discuss possible links with other academic departments.

The breadth of backgrounds necessary to do justice to the topic suggests a course with instructors from different disciplines, and the paper will include discussion of this option. While this is difficult to arrange in the common university environment, the result would be a better course, and this arrangement would be helpful in attracting students. Even if only one instructor is assigned, interested faculty in other departments can help to improve the course and to attract more students.

Introduction

Examples of technological developments affecting human society and of human society's efforts to channel technological development are found throughout human history. Despite the long record of historical evidence of their impact on society, our standards for an educated person do not include any study of technology or of engineering. Efforts to include technological literacy in education ${ }^{1}$ seek to address this omission.

Our standards for an educated individual have a direct link to the distant past. We can match much of our current general education core requirements to the seven liberal arts as defined in the Middle Ages and drawing on earlier times: the trivium of grammar, rhetoric, and logic, and the quadrivium of arithmetic, geometry, astronomy, and music. ${ }^{3}$ If you compare this to the general education core at the author's university, students are now required to complete courses in composition and public speaking (grammar and rhetoric), mathematics (arithmetic \& geometry), natural sciences (the offerings include astronomy), and the humanities (music and the 
other fine arts). The university core also includes history and the social sciences. While logic is the subject of a specific course or courses in philosophy, students are required to hone their skills in grammar, rhetoric, and logic in all of these courses. As the body of human knowledge has expanded and divided into more subfields, the list of specific subjects in core requirements has expanded. It has not expanded, however, to include engineering or technology. As noted by Bugliarello, these topics need to be need to be included in a modern quadrivium. ${ }^{2}$

While the topics currently included in the university core are important for an educated person, they are not sufficient. The very function of modern human society depends on technology and the engineering expertise necessary to develop and manage that technology. While the questions of how things work can be answered based on knowledge of physical science, this alone is not sufficient to explain how things can be made to work and how things come into being. The study of science alone does not explain how things are designed and made, whether those things are individual devices, or the systems necessary for their manufacture and use. Science alone may be sufficient to explain the proposed mechanism for global warming, yet getting from the problem to a solution without catastrophic disruption to human society requires more than just scientific knowledge; it requires engineering knowledge and the ability to use technology.

How do we add the study of engineering and technology to the curriculum? How do we attract students? What are we, as engineering and engineering technology faculty, best prepared to teach about engineering and technology?

The most straightforward method for us as faculty to address this issue is to offer a course (or courses) in technological literacy. For this to be successful, we must develop a course that both serves the purpose of teaching technological literacy and is clearly relevant to non-majors and we must be able to attract students to this course. In content and assignments, the course will be a significant departure from most engineering courses, as we will be taking a broad view of engineering and technology, instead of focusing on specific areas of knowledge needed for engineering practice. The course must take a broad view of technology and of engineering, and must examine the effects of technological change on society as well as the influence of society on technological change. This goes into the realms of business, politics, sociology, and history. Engineering education has not traditionally included this sort of study; one could argue that this omission has been detrimental to the profession.

Recognition of need and interest in this area is growing, as evidenced by efforts by the National Academy of Engineering ${ }^{1}$ and the National Science Foundation ${ }^{4}$ and the development of an active group in the American Society for Engineering Education. A small and growing number of institutions have developed and offered a course or courses to help non-majors learn about engineering and technology, and about the relationship between technology and society. A review of twelve such courses is given by Ollis and Krupczak ${ }^{5}$. The concept of technological literacy appears to have evolved along with some of these courses, leading to interest in developing formal standards for assessment ${ }^{6,7}$.

The author's department has for some time had a course in the bulletin called "Technology and Society." Several years ago, the opportunity presented itself for the author to teach this course with a target of offering the class at least once a year. This is an upper level course, making it 
useful as an elective course and especially attractive to community college graduates seeking a bachelor's degree and needing to meet upper division credit requirements. Prior to that, the author had the very pleasant and intellectually challenging experience of working in partnership (as the junior partner) with a colleague in the history department who wanted to offer a course in the history of technology. Finally, the author is the primary instructor for our introductory course for freshmen entering our program. The mission of our introductory course for new majors has some things in common with the mission of a course introducing engineering and technology to non-majors.

Others have been down the same path and have reported on their experiences in developing courses and attracting students. ${ }^{4,5 ; 8}$ The content, approach, and level of existing courses vary. Some institutions have accepted the course into the general core to meet natural science requirements. Many courses focus on how things work and include laboratory components. The course discussed in depth by David Ollis ${ }^{8,9,10}$ evolved from a device dissection course for first year engineering students, and has a strong lab component in that area linked to discussion of context and content. Some courses, such as the course developed by John Krupczak at Hope College, link discussion of technology to the scientific principles behind the device. ${ }^{5}$ Many of the courses are designed for first year students, such as the courses described by Ohland ${ }^{11}$ and Soysal and Soysal. ${ }^{12}$ Two common goals are to help students understand engineering and to make informed decisions about technological issues facing society. Rosa et al described a one year course sequence along these lines. ${ }^{13}$ Carlson argues for a broad perspective focusing on the interaction of society with technology, and uses historical examples as case studies. ${ }^{14}$

Taken together, it appears that courses have evolved in part to meet needs at specific institutions. This paper will share the author's experiences to date in introducing and attracting students to a course in technological literacy at the author's institution.

Finding Students for the Course

This experience with course development and teaching technological literacy comes in the context of a small state university with a history as a normal school and a more recent designation as a liberal arts university. In addition to common programs found in a college of arts and sciences, the school also has programs in education, business, and nursing. The institution has a satellite campus, where the university offers degrees in criminal justice and professional studies, as well as other areas. The criminal justice program has an emphasis on homeland security.

Ideally, the importance of technological literacy would be recognized by faculty colleagues across academic disciplines and by administrators, and a course in technological literacy would be added to core requirements for all students. This is unlikely to occur. As noted, the common core requirements focus on traditional topics - composition and public speaking, history, humanities, social sciences, mathematics, and natural sciences. A recent mandate from the state has reduced the size of the core and reduced local control over core contents. The same mandate restricted the number of credit hours that we could require for degrees. In this environment, the chances of getting a course in technological literacy added as a university-wide requirement are slim. 
We can offer a technological literacy course as an elective course for students who have room in their major requirements for open electives. This option has serious limitations. Students have many choices available to them to meet open elective requirements. This may include courses in their majors. For some reason, students who are not engineering majors seem to be intimidated by any sort of engineering prefix on a course title. Also, if they understood why this course would be important to them, then they would have already achieved some degree of technological literacy. We cannot expect that to be the case.

At my institution, the best hope for attracting students to a technological literacy course is to focus initially on specific majors where an understanding of technology and of engineering would be directly applicable in the major itself. Here, one could seek assistance in reaching students from faculty advisors in these areas. A business major seeking eventual employment with a company that also hires engineers should see the wisdom of learning something about engineering and technology while in college. An English major specializing in technical writing should be interested for the same reasons. In reading works to prepare to teach a technological literacy course, one is struck by the number of scholars in history and sociology who study engineering and technology. Just as engineers can learn from the historians and sociologists, the history or sociology major interested in pursuing an academic career in these fields should be encouraged to learn more from engineers about engineering and technology. While majors in mathematics and physical science will have more affinity for engineering and technology, they need help understanding the differences between their fields and engineering. Many math and physical science majors go on to teach in secondary schools, where they are likely to be guiding students for whom engineering would be a good career choice, and they may be tapped to teach technological literacy at the secondary school level. For them to do this successfully, it is important for them to learn more about engineering and technology from engineers.

A desire to attract graduates of associate's degree programs at community colleges led the author's institution to develop a new degree program. This program in professional studies is designed to take students with associate's degrees from a wide range of fields and allow them to finish a bachelor's degree in two years. This new program offered a unique opportunity. As the program was just being started, the program was short on faculty and courses, and other departments were solicited to offer courses for the new program. This gave us an opportunity to have the technological literacy course listed as a major requirement, resulting in a reasonable number of students (around twenty) for one section per year. This was very helpful in getting the course established. As the professional studies program has added faculty and developed more of their own courses, the technological literacy course has been changed from a requirement to an elective. Even as an elective, the course continues to draw students from that program.

Another group of students who should be interested in technological literacy course are those interested in homeland security and terrorism issues. The 9-11 attackers turned technological artifacts - commercial aircraft - into weapons, demonstrating the vulnerability of technological systems to being turned to sinister purposes. Both the threats and the countermeasures involve technology. Students with an interest in security and terrorism prevention need to develop an understanding of technological systems and of the potential and the limitations of defensive technology. 
The best way to reach these students is through their academic advisors. Outreach to other departments by the professor teaching the course can help get students into the technological literacy class. Also, this can encourage participation in the technological literacy course by people in other relevant fields, and can help guide course development to make the technological literacy content more relevant to these areas.

Content of the Course

In its current form, our course in technological literacy follows the format of a lecture course. The course is still under very much a work in progress. As we found a market for the course in a new degree program that was offered primarily on-line, the course has only been offered successfully as a web class.

The focus of a course in technological literacy can be drawn from the definition of a technologically literate person found in the report of the National Academy of Engineering Committee on Technological Literacy, Technically Speaking. In that report, technological literacy is described as having three dimensions: knowledge, ways of thinking and acting, and capabilities. ${ }^{15}$ To date, the institution-specific need that the course be available as a web course has precluded a laboratory component, which would be the best environment for teaching aspects of how things work. Therefore, the course emphasizes the two dimensions, of knowledge and ways of thinking and acting, which emphasize a broader scope of knowledge and questions to ask when dealing with technological issues.

The objective of our technological literacy course is to help students better understand technology, the effects technological developments have on society and how societal considerations affect technological development. In setting up the course objectives, the author felt that the course should give students:

- A basic appreciation of technology and of the engineering profession,

- A better vision of how technological progress occurs,

- A recognition of how technological change affects the way people live, and an awareness of both the positive and negative results of that change,

- A sense of both the potentials and the limits of technological progress,

- An appreciation of the effect technology has had on the development of civilization, and

- A vision of where we can go from here, including problems facing human society that are linked to technology.

Lists of similar learning objectives from some well established technological literacy courses are given in Krupczak and Ollis. ${ }^{5}$

Some of these goals are also goals for a course introducing engineering to majors in engineering or engineering technology degree programs. Other topics are best approached by using case studies, either historical studies or current events. As noted in Technically Speaking, engineering students develop technological competency rather than literacy, and would benefit from the study of topics in a technological literacy course. ${ }^{16}$

To illustrate these points, the author starts with definitions of engineering and of technology. Regarding technology, it is important for us to address one common misperception: that technology is limited to information technology. The author has observed among students and 
both faculty and administrators, including people who should be among the most receptive to a course in technological literacy, a strong misperception that technology means only information technology. Ollis also notes this as a concern. ${ }^{17}$

This discussion of engineering and technology is followed by presentation and discussion of examples of engineering practice and technological progress, including both personal stories and stories from other sources. Of the personal stories, the author uses the old family home as a showcase for how technological developments have changed the pattern of daily life. This house dates from 1900, and this artifact can lead to exploration of a variety of technological developments. This discussion suggests to students that they can observe a record of technological change in their own environment, be it an old home in their family, a museum, or the local landscape. A number of sources are available for stories of technological development; the author has included a listing, albeit incomplete, of sources consulted for this course. Taken together, these stories can help students recognize the positive and negative outcomes from technological change, and the process of society influencing technological change and of technological change influencing society. It should also help the students to understand the process of technological change, including issues in engineering practice, design, manufacture, and operation.

The course should help students recognize problems facing human society that are related to technology. The course includes material on energy, the environment, and sustainability. Material on these topics can come both from texts and from current news stories; including the latter helps students connect this study with international, national, and even local issues.

Materials and Texts

To help students understand the purpose of the course, the author has assigned parts of Technically Speaking. This is available as a paperback book and over the web. Traditional textbooks are available for courses in technological literacy, such as Dorf, Technology, Humans, and Society, ${ }^{18}$ and Hjorth et al, Technology and Society. ${ }^{19}$ Both have a strong focus on areas of current concern, such as energy, the developing world, the environment, and the overarching theme of sustainability. Another text that, regrettably, is out of print is Johnston et al, Engineering and Society. ${ }^{20}$ Unlike the first two books, this was written for senior engineering students in a capstone course. While including some of the same topics, such as energy and sustainability, the focus of this text is on engineering practice. This is beneficial for a technological literacy course. The text is useful both for new engineers confronting issues in the political and business arenas and for non-engineers needing to understand engineering.

The author wanted material in the readings that would serve as case studies in engineering and technology, and used other books to supplement standard textbooks. Some books written for first year engineering students, such as Adams, Flying Buttresses, Entropy, and O-Rings: the World of an Engineer, ${ }^{21}$ and Billington, The Innovators: the Engineering Pioneers Who Made America Modern ${ }^{22}$ can be used for this purpose. While they were written to introduce engineering to newcomers, they can be used for non-majors in technological literacy courses. The author uses Adams for a freshman course, and has used Billington for both freshman and technological literacy courses. Adams writes about the present, while Billington writes about engineering advances in the United States during the $19^{\text {th }}$ century. A new book by Billington 
focuses on advances in the $20^{\text {th }}$ century. While Billington does include some equations which may frighten non-majors, this material does not have to be emphasized, and the discussion is such that it can be used to introduce non-majors to calculations and analysis in engineering.

Case studies in engineering and technology can come from a variety of books on engineering and technology. For our needs, a case study written for a general audience may be better for students than a more detailed and rigorous, but less readable, scholarly account. Books by Henry Petroski and John Lienhard are very useful sources. The author has gotten very positive comments from students on Tobin, Great Projects, ${ }^{23}$ which led to a documentary series on PBS. The book presents selected engineering projects in the United States, ranging in time from improvements in navigation and flood control on the Mississippi River through the Internet and the Central Artery, or "Big Dig," project in Boston. The material on the Central Artery project can be augmented with current news accounts of recent problems with the tunnel system. Other options in a similar vein are Constable and Somerville, A Century of Innovation, ${ }^{24}$ the result of a National Academy of Engineering project, and Evans, They Made America. ${ }^{25}$

Scholarly literature in history and sociology can yield high quality case studies and broader discussions of technology and society. While such sources may be beyond the level of students, they are very useful for professors teaching these courses. There are a number of texts on the history of technology; Cowan's Social History of American Technology ${ }^{26}$ is just one example. Two books, Thomas Hughes' $\underline{\text { Human Built World }}^{27}$ and David Nye's Technology Matters ${ }^{28}$ are noteworthy as valedictory works by noted historians who have studied technology and engineering. Vincenti's study of aeronautical engineering, What Engineers Know and How They Know It ${ }^{29}$ is a very interesting study of engineering practice. Finally, Rhodes' Visions of Technology, ${ }^{30}$ a collection of quotations and excerpts on technology from the $20^{\text {th }}$ century, offers a wide selection of topics for discussion. It is an unrealized intention of the author's to use this as the basis for a technology-thought-of-the-day feature as part of the web-based technology and society course.

References from business can also be useful. Several books on the subject of technological developments by Christensen et $\mathrm{al}^{31}$ develop a series of theories of innovation which can be used to predict industry change. Many of the examples, such as the displacement of the telegraph by the telephone, focus on technology, and would be useful additions to a course in technological literacy.

In addition to books, the journal of the Society for the History of Technology (SHOT), Technology and Culture, is a source of both scholarly case studies and reviews of books in the field. The periodical publication of the National Academy of Engineering, the Bridge, the IEEE publication, Technology and Society, and the American Heritage of Invention and Technology magazine are also useful sources.

Course Content - What Do We Teach?

In the author's opinion, a technological literacy course is not a perfect match for an engineering professor. As noted in Technically Speaking, engineers are technologically competent. Engineering professors are prepared to teach courses in specific areas of engineering. This is different from teaching technological literacy. In teaching aspects of technological literacy, we 
are in effect looking at the engineering field from the outside. The material for use in the course often comes from historians and sociologists; as noted by Carlson, there is a need for engineers to collaborate with historians and sociologists in this area. ${ }^{14} \mathrm{We}$ are trained to be engineers and to do engineering work. We are not trained to be historians or sociologists. We are at a disadvantage if we try to teach as if we were historians or sociologists.

Better than trying to be something we are not, the author believes the best approach is to teach as engineers who are introducing engineering and the engineer's perspective on technology to outsiders. While we use material from experts in history and sociology, we do best to be who we are - engineers. We can explain engineering practice. We can explain aspects of engineering design and manufacturing. As noted by Ollis and Krupczak, this type of course is a good fit to faculty specializing in design. ${ }^{32}$ We can highlight the difference between the practice of engineering and science. While we need to bring in issues that are best studied by sociologists and historians, we should not try to remake ourselves as historians or sociologists, and we should not neglect our expertise in the process.

If the university had a structure for instructional teams, an ideal team would match an engineering professor with a professor from history or sociology (or both) who is interested in the study of technology. The author was fortunate enough to have this sort of experience when a colleague in the history department wanted to teach a course in the history of technology and wanted to have an engineer assist with the course. The author found this an extremely enjoyable and humbling experience. In that course, the instructors each took on different topics. Based on that experience, the author would recommend that both instructors take on the same topics, with the historian discussing economic and social effects while the engineer discusses technological issues. Taking mass production manufacturing as an example, the historian is best prepared to discuss the effects of the new technology on society, while the engineer is best prepared to explain machine tools, variation and control of variation in mass manufactured goods, and other technological issues.

Regrettably, university teaching load accounting is tied to single instructor courses and to courses being offered from individual departments. Unless one of the instructors wishes to teach for free, it is difficult, if not impossible, at most universities to set up a course with multiple instructors teaching for load. Given that situation, the best we may be able to hope for is to find interested faculty in other departments, such as history, sociology, and business, who are willing to help in their areas with advice and, perhaps, the occasional guest lecture.

Recommendations for a Better Course

As it stands, the author's course follows the lecture course format. It would be desirable - and fun - to include hands-on activities for students. As noted earlier, many courses do include lab components, and some have a strong component of device dissection. ${ }^{5 ; 8-10 ; 13}$ The sort of simple design and build projects being used by some in introduction to engineering courses could also demonstrate engineering concepts to non-majors. ${ }^{19}$ George et al describe a successful effort to integrate a hands-on project in a technological literacy course for non-majors. ${ }^{20}$ These activities can be fun as well as informative, adding to the appeal of the course. This would be relatively easy to incorporate in the classroom, but more of a challenge with web-based courses. 
It is also highly desirable to link the class activities with current events. These can be the basis for case studies or can add to existing case studies. The author makes use of articles from newspapers on a range of topics. The northeast power failure of 2003 served to highlight a number of issues, including our society's dependence on electrical power, infrastructure issues, and how relatively small events can have catastrophic effects on engineering systems.

One of the author's goals is to help students develop a vision of the future. Material from the field of future studies can be used to add this dimension to the course. Also, visions of technology's impact on society abound in science fiction, and a "movie night" could be both useful and fun for students.

\section{Conclusion}

Developing a technological literacy course has proven to be a very challenging, yet rewarding, assignment with great potential benefits for students. It is a challenge for the instructor, as the course takes the instructor outside of his or her comfort zone, and forces them to address broader issues. This author concurs with Ollis ${ }^{35}$ that, for the individual taking on the course, this can be a very rewarding experience. At this time, there is significant diversity among courses being

offered in this area. ${ }^{5}$ Even with the push for development of common standards for these courses, ${ }^{6,7}$ there should still be room for the instructor to adapt a course to the specific needs of their institution. Attracting students to the course may be a challenge, however, there is benefit for the instructor, the department or school, and to society when this challenge is met.

Bibliography

1. Technically Speaking - Why All Americans Need to Know More About Technology, National Academy Press, Washington, DC, 2002. ISBN 0-309-08262-5.

2. Bugliarello, George

3. Random-House College Dictionary, Random-House, NY, 1984, pgs 1079 \& 1407.

4. Krupczak, John, and David F. Ollis, Improving the Technological Literacy of Undergraduates - Identifying the Research Issues, National Science Foundation, 2005.

5. Krupczak, John, and David Ollis, Technological Literacy and Engineering for Non-Engineers: Lessons from Successful Courses, Paper No. 2006-744, Proceedings of the 2006 American Society for Engineering Education Annual Conference \& Exposition.

6. Gorham, Douglas, Pam. B. Newberry, and Theodore A. Bickart, ABET and Standards for Technological Literacy, Proceedings of the 2003 American Society for Engineering Education Annual Conference \& Exposition.

7. Krupczak, John, Greg Pearson, and David Ollis, Assessing Technological Literacy in the United States, Paper No. 2006-701, Proceedings of the 2006 American Society for Engineering Education Annual Conference \& Exposition.

8. Ollis, David F., Installing a "Technology Literacy" Course: Trials and Tribulations, Proceedings of the 2004 American Society for Engineering Education Annual Conference \& Exposition.

9. Ollis, David, Technological Literacy: Connecting through Context, Content, and Contraption, Proceedings of the 2005 American Society for Engineering Education Annual Conference \& Exposition.

10. Ollis, David, Teaching Technological Literacy as a Quest, or "Searching for Self in the Engineering Cosmos," Paper No. 2006-647, Proceedings of the 2006 American Society for Engineering Education Annual Conference \& Exposition.

11. Ohland, Matthew, First Year Engineering Programs and Technological Literacy, Paper No. 2006-1282, Proceedings of the 2006 American Society for Engineering Education Annual Conference \& Exposition. 
12. Soysal, Hilkat, and Oguz Soysal, Freshman Course on Science Technology and Society, Paper No. 20061822, Proceedings of the 2006 American Society for Engineering Education Annual Conference \& Exposition.

13. Rosa, Albert J., Paul K. Predecki, and George Edwards, Technology 21 - A Course on Technology for Non-Technologists, Proceedings of the 2004 American Society for Engineering Education Annual Conference \& Exposition.

14. Carlson, W. Bernard, Technological Literacy and Empowerment: Exemplars from the History of Technology, Paper No. 2006-1182, Proceedings of the 2006 American Society for Engineering Education Annual Conference \& Exposition.

15. Technically Speaking, pp 14-17.

16. Ibid, pg. 22

17. Ollis, David, and Greg Pearson, What is Technological Literacy and Why Does It Matter?, Paper No. 2006-695, Proceedings of the 2006 American Society for Engineering Education Annual Conference \& Exposition.

18. Dorf, Richard C., Technology, Humans, and Society - Toward a Sustainable World, Academic Press, San Diego, CA, 2001. ISBN 0-12-221090-5.

19. Hjorth, Linda S., Barbara A. Eichler, Ahmed S. Khan, and John A. Morello, Technology and Society - A Bridge to the $21^{\text {st }}$ Century, ${ }^{\text {nd }}$ Ed., Prentice-Hall, 2003. ISBN 0-13-092475-X. Note: the $3^{\text {rd }}$ edition is now on the market.

20. Johnston, Stephen F., J. Paul Gostelow, and W. Joseph King, Engineering and Society, Prentice Hall, 2000. ISBN 0-201-36141-8.

21. Adams, J.L., Flying Buttresses, Entropy, and O-Rings: the World of an Engineer, Harvard University Press, Cambridge, MA, 1991. ISBN 0-674-30689-9.

22. Billington, David P., The Innovators: the Engineering Pioneers Who Made America Modern, John Wiley \& Sons, NY, 1996. ISBN 0-471-14096-1.

23. Tobin, James S., Great Projects - the Epic Story of the Building of America, from the Taming of the Mississippi to the Invention of the Internet, the Free Press, 2001. ISBN 0-7432-1064-5.

24. Constable, George, and Bob Somerville, A Century of Innovation - Twenty Engineering Achievements that Transformed Our Lives, John Henry Press, Washington, DC, 2003. ISBN 0-309-08908-5.

25. Evans, Harold, They Made America, Little, Brown, \& Co., NY, 2004. ISBN 0-316-27766-5.

26. Cowan, Ruth Schwartz, A Social History of American Technology, Oxford, 1997. ISBN 0-19-504605-6.

27. Hughes, Thomas P., Human Built World - How to Think About Technology and Culture, University of Chicago Press, Chicago, IL, 2004. ISBN 0-226-35933-6.

28. Nye, David, Technology Matters - Questions to Live With, MIT Press, Cambridge, MA, 2006. ISBN 0262-14093-4.

29. Vincinti, Walter G., What Engineers Know and How They Know It - Analytical Studies from Aeronautical History, Johns Hopkins Press, Baltimore, MD, 1990. ISBN 0-8018-3874-2.

30. Rhodes, Richard, Visions of Technology - A Century of Vital Debate About Machines, Systems, and the Human World, Touchstone, NY, 1999. ISBN 0-684-83903-2.

31. Christensen, Clayton M., Scott D. Anthony, and Erik A. Roth, Seeing What's Next - Using the Theories of Innovation to Predict Industry Change, Harvard Business School Press, Boston, MA, 2004. ISBN 1-59139185-7.

32. Ollis, David, and John Krupczak, Teaching Technology Literacy: An Opportunity for Design Faculty?, Paper No. 2006-648, Proceedings of the 2006 ASEE Annual Conference \& Exposition.

33. Freeman, Susan, Beverly Jaeger, and Richard Whalen, Active Teaching, Active Learning: Infusing the Design Process in a First-Year Course, Proceedings of the 2006 ASEE Annual Conference \& Exposition.

34. George, Camille, Elise Amel, and Karl Mueller, A Solar-Powered Decorative Water Fountain Hands-On Build to Expose Engineering Concepts to Non-Majors, Proceedings of the 2006 ASEE Annual Conference \& Exposition.

35. Ollis, David, Teaching Technological Literacy as a Quest, or "Searching for Self in the Engineering Cosmos," Paper No. 2006-647, Proceedings of the 2006 ASEE Annual Conference \& Exposition. 